\title{
Kinship and relatedness in urban Papua New Guinea
}

Parenté et relations en Papouasie Nouvelle-Guinée urbaine

\section{Fiona Hukula}

\section{(2) OpenEdition \\ 12 Journals}

Electronic version

URL: http://journals.openedition.org/jso/7756

DOI: $10.4000 /$ jso. 7756

ISSN: $1760-7256$

Publisher

Société des océanistes

\section{Printed version}

Date of publication: 15 December 2017

Number of pages: 159-170

ISSN: 0300-953x

\section{Electronic reference}

Fiona Hukula, "Kinship and relatedness in urban Papua New Guinea", Journal de la Société des

Océanistes [Online], 144-145 | 2017, Online since 15 December 2019, connection on 15 March 2021.

URL: http://journals.openedition.org/jso/7756 ; DOI: https://doi.org/10.4000/jso.7756

\section{(c) $\left(\right.$ ) $\odot \Theta_{\text {EY NC ND }}$}

Journal de la société des océanistes est mis à disposition selon les termes de la Licence Creative

Commons Attribution - Pas d'Utilisation Commerciale - Pas de Modification 4.0 International. 


\section{Kinship and relatedness in urban Papua New Guinea}

by

Fiona HUKULA*

\begin{abstract}
Early anthropological literature on urban Port Moresby (Papua New Guinea) highlights the importance of urban-rural kin connections and the village flows into town and vice versa. While this is still important, this article focuses on contemporary kinship and relatedness in an urban settlement in Port Moresby and how relations there are made evident through everyday actions of exchange and sharing of food, time, and consideration. People in town build kin-like relations using the concept of wan, particularly wantok (same language), wanstrit (same street), and wanlotu (same religion), as they share resources, support neighbourhood marriage and funerary rituals, and as employers and employees become kin. Kinship in Port Moresby, though constrained in many ways, is acted out in forms that are rooted in urban place, space, and home.
\end{abstract}

KeYwords: urban life, kinship, Melanesia, Port Moresby, settlements

Relatedness and ideas of kinship are an important part of social life and social order in Port Moresby. They affect ways in which people think about each other, help each other and address conflict, among other things. This article aims to contribute to the discourse of kinship and urban Melanesia by making a case that kinship in Port Moresby, though constrained in many ways, is acted out in forms that are rooted in urban place, space, and home. Drawing from the work of Gow (1991), Carsten (2000,

\section{RÉSUMÉ}

Les premiers textes anthropologiques sur la Papouasie Nouvelle-Guinée urbaine ont insisté sur les liens de parenté ville-village, et sur la façon dont le village s'épand en ville et vice-versa. Bien que cela soit encore important, cet article met l'accent sur les liens sociaux et de parenté contemporains dans un quartier de Port-Moresby. Il montre comment les citadins établissent des liens sociaux de type familial en partageant de la nourriture, du temps et des idées. Utilisant le concept de wan dans des mots comme wantok (même langue), wanstrit (même rue) et wanlotu (même religion), ils indexent des relations quasi familiales construites par le partage des ressources, les soutiens offerts lors des mariages et des obsèques dans le quartier, et par l'intégration d'employeurs et d'employés à la famille. Même si la parenté est contrainte de bien des façons, elle est mise en scène sous des formes enracinées dans l'espace et le monde urbain, et le village.

Mots-CLÉs : vie urbaine, parenté, Mélanésie, Port Moresby, quartiers résidentiels

2004), Leach (2003) and Bamford (2007, 2009), this article describes how people talk about relatedness and the sorts of actions that inform ideas of relatedness and how relations and competing interests such as giving and not giving are managed. To illustrate this point more clearly, I offer several ethnographic examples.

I draw on 15 months of doctoral fieldwork in 2009-2010 in an urban settlement called Morobe Blok $k^{1}$ I lived in Morobe Blok where I followed the lives of several key informants,

1. Tokpisin spelling for Block

* The national research Insitute, Papua New Guinea, fhukula@nri.org.pg 


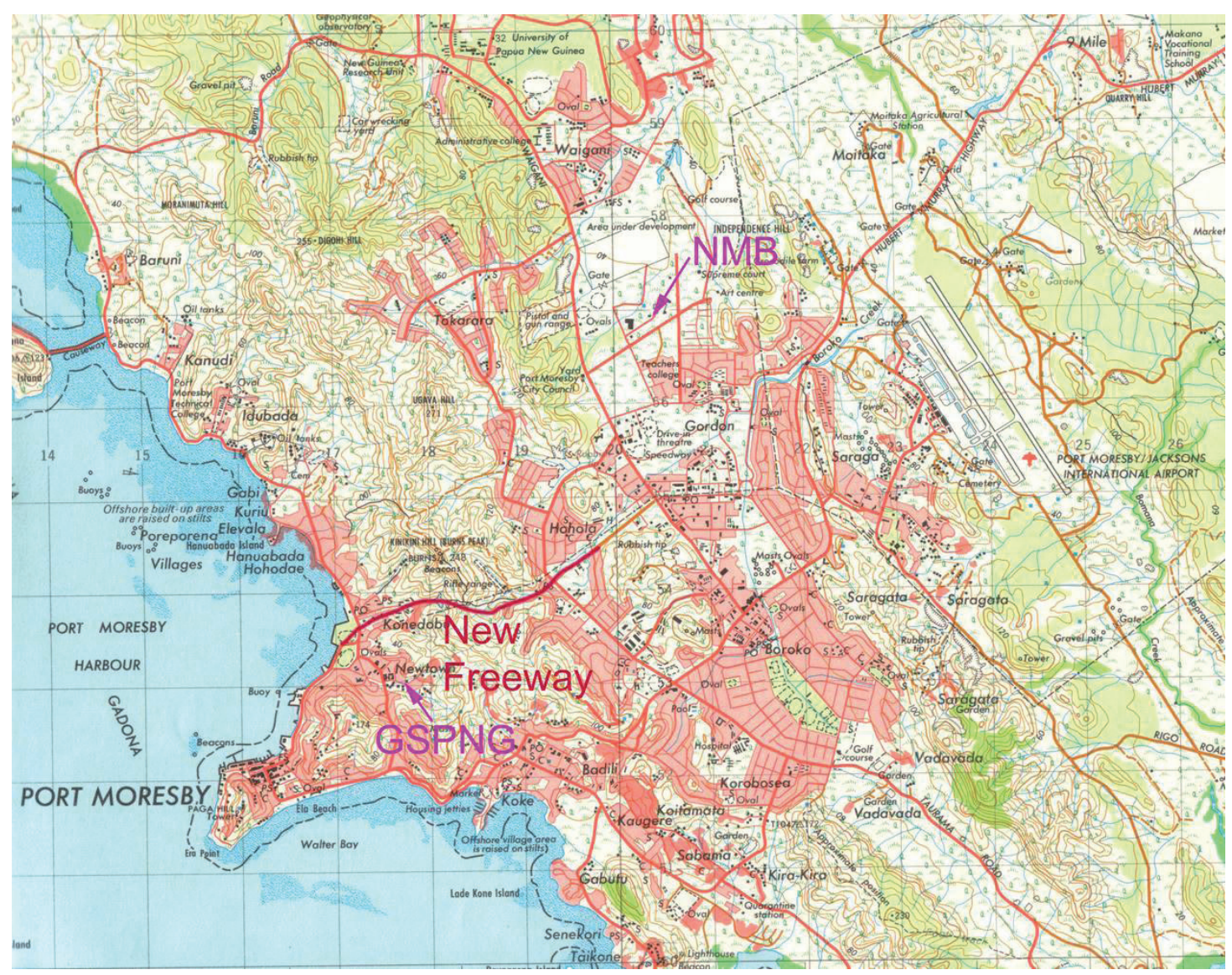

MAP 1. - Morobe Blok (NMB), Port Moresby

interviewed Blok residents and Blok leaders, and conducted a mini household survey.

Situated on the outskirts of Port Moresby, Morobe Blok is a settlement of approximately $5,000^{2}$ people that is predominately made up of people from the Morobe Province of Papua New Guinea (map 1).

Morobe Blok was founded around 1992. The settlement was created after Morobeans living at another ethnically mixed settlement community in the Six Mile area of Port Moresby, commonly known as Saraga Street, decided to seek another place in Port Moresby to shelter after several incidences of violence raised anxiety and worry about safety and security. The Morobeans at Six Mile felt that they needed to move to a place where they could live among themselves and pursue their lives in a manner that did not leave them feeling threatened. The anxiety and worry of those at Six Mile were relayed to Sondiong Babago, a man from the Wain area of Morobe who lived among the Koiari people of the Sogeri Plateau. The Koiari people of the Sogeri Plateau make customary land ownership claims to land around the Nine Mile area beyond the city boundaries.

Various versions of this story were told to me by several informants. One of them was the chairman of the Blok, a man named Atisinke. The chairman of the Blok is the elected leader of the settlement community. He is part of a komiti (committee) of men who have been elected by the residents to represent the interests of the members of the different electorates of Morobe Province who reside at the Blok. This komiti serves as a conduit between the papa graun (land owners) and other parties such as the National Capital District Commission.

Morobeans who first settled at Nine Mile were allocated plots of land according to the electoral boundaries of their home province. Although the evidence of settlement in electoral boundaries is not so clear now, this intention is still evident with people from the different electorates living in close proximity to each other and in some cases in clusters of houses of close kin. Residential arrangements according to ples is not uncommon as shown by Lindstrom's (2011)

2. According to the 2000 Papua New Guinea National census the population of the entire Nine Mile settlement area is 5,000. I arrive at this estimate population via two sources: The first from the settlers themselves, the chairman included; and the second via an estimation based on a mini household survey that I conducted in the settlement. 
description of how Tannese migrants in Port Vila reproduce the village.

Like other urban settlements in urban Melanesia (Lindstrom, 2011; Rooney, 2015; Carpenter and Munro, 2016), Morobe Blok residents are engaged in various forms of income generation which include being employed in the public sector as well as in the private sector as security guards, construction workers, and hospitality industry workers. Others earn a living solely through the informal economy while many households supplement their income by engaging in the informal economy through the sale of betel nut, cigarettes, and garden produce.

\section{Relatedness and kin - the non-genealogical model in the Blok}

Peter Gow (1995) studied kinship among native people living on the Bajo Urubamba in Peru collecting stories about land, as well as through observing how they used the land and the ways this mediated their relations with other people. Gow writes,

"In truth, I did not learn of the centrality of kinship for native people through the classical anthropological techniques. I found the famous 'genealogical method' rather embarrassing to use, for my informants were either insulted or aggrieved by my objectification of their kinship relations." (Gow, 1995: 48)

In a similar fashion, I learnt about Blok ideas of kinship and relatedness not through the collection of genealogies, but by listening to the stories that people told about their daily interaction with other people and places. It was next to impossible for me to document genealogies the "traditional" way because people in the Blok refer to each other as brata, susa, mama, kandre (brother, sister, mother, nephew) regularly in everyday conversation and attempts to find "real" blood relatives proved futile. I would ask someone how they were related to another person and I would usually get a reply of

\footnotetext{
"We are sisters, our tumbuna's (ancestors) came from the same place."

While many people do place their relations quite specifically, there is also a level of vagueness. I asked Blok residents how they knew people who were not related by blut (blood) and I would often get a reply of
}

"Oh, she is my sister or he is my brother, we grew up together that is how I know them."

Over the course of my fieldwork, I came to know the extended kin of the families that I clo- sely associated with. However, most people were quite vague about how they were related to each other. This vagueness does not indicate that one does not know who his or her kin is. It was more the case that people knew their connections to each other and did not need to go into grand explanations of genealogies.

Relatedness through a sense of similarity of origin in a place like Morobe Blok, where one who is not Morobean may be seen as different, is a way that people establish and maintain a sense of connection. It also shows that coming from the same province is not always a defining character of relations in the Blok, but can serve also to emphasise difference. I observed that groups are formed and disbanded according to perceived needs; therefore, Blok residents are united as Morobeans when they need to show solidarity or amass materials for payments such as annual rents to the landowner. However, this solidarity is not static and constant and changes over time to suit different social situations. I mentioned earlier that many people refer to, or address, one another by using kinship terminology. Yet the loose use of kinship terms in everyday conversation and interaction must not be interpreted only as an observation of the use of language to describe what is considered as a socially correct way to address others, especially people who are older. I observed how kinship terms such as "sister" and "mother" were acted upon through caring, sharing, eating food together, and through the recollection of historically shared stories. Thus the kin term is not sufficient to designate existing relations but becomes a medium that is combined with action.

Writing about the Reite of Madang, James Leach (2003: 29) noted the importance of drawing substances for growth from the land. People share substance, and are therefore kin because they have grown in the same land. For Leach, kinship is not about descent through genealogy, but is an outcome of the relations between people and the land. Leach states,

"Persons, constituted by kinship relations of shared substance, are not joined to places constituted by geographical relations of spatial propinquity. Rather the constitution of persons are mutually entailed aspect of the same process. In this sense kinship is geography of landscape." (Leach, 2003: 31)

For Morobe Blok residents, notions of kinship are expressed through feeding and eating as well as good will and thoughts. To think about someone is an important expression of relatedness. The phrase

“yu save tingim mi tu o?" [Do you think of me?]

is one that is used as a reminder of obligations that people have to one another. These obliga- 
tions are not necessarily material in nature but encompass other actions, such as visiting and telling stories. People create relatedness through the experience of living together in the same place.

\section{Relatedness and kinship through Wan}

I focus on how forms of relatedness are shaped by ordinary everyday activities in order to show how these interactions influence the way in which relations are produced (Carsten, 2004: 9). Janet Carsten asserts that kinship is, among other things, an area of life where people invest their emotions, their creative energies and their new imaginings. To this effect, I use the term relatedness alongside kinship as a way of describing and analysing Blok relations that evoke what can be identified as traditional kinship terms (such as mother, father, brother, sister). Here I want to concentrate on the use of the term wan to show relatedness and kinship in the Blok.

My use of the word wan is rooted in the Tok Pisin word wantok. Wantok literally means "one talk". The term wantok is most commonly associated with being from the same province or region. Hence the literal English translation of "one talk" means to speak one language. Wantok is often referred to as a social safety net-system (Monsell-Davis, 1993; Nanau, 2011; Mohanty, 2011) which offers social protection and security for Papua New Guineans and other Melanesians. It is also considered a system that enables people to thrive in business and politics at the expense of others who are not party to a particular wantok system that accords access to such benefits. Paulo de Renzio (2000), borrowing from Mannan (1978), loosely defines the wantok system as the system of relationships (or obligations) between individuals characterised by some or all of the following:

(a) common language;

(b) common kinship group;

(c) common geographical place of origin;

(d) common social associations and religious groups.

Schram (2015: 4-5) discusses the wantok relationship as a conceptual apparatus within a discourse of towns and villages. While Schram offers an analysis of the rural-urban dichotomy as sharing a common logic of segmentary kinship, my focus is soley on urban relations. My intention here is to provide a contemporary account of how relatedness is imagined and performed in everyday urban life. My account of relatedness moves beyond the definition of wantok in urban kinship discourse to a description of what makes relatedness and how wantok and other similar words are lived.
While I do not go as far as Charles Stafford's (2000) reference of relatedness as literally anykind of relations between persons, I place relatedness and the different forms and understanding that it takes in various contexts. This is not only based on blood and wantok ties but also through reciprocal sharing, and the lived experience of place-based connections such as wanlotu (one church), wanskul (school mate), and wanstrit (neighbours). Wantok may encompass other relations that are defined through place, religious activities, work, and bounded history. I want to contribute to the discourse of wantokism by arguing that in order for wantok and relatedness to be active beyond definitions and descriptions, certain capacities and qualities must be activated and utilised in a way that informs this feeling of relatedness. It is with this in mind that I focus on relatedness and the wan aspect of how Blok people recognise and define forms of relatedness. For the purpose of this discussion, I use the Tok Pisin word wan as opposed to the English word "one" as a way to draw out the linguistic possibilities of wan such as wanstrit (one street), wanskul (one school), wanlotu (one church), and its influence in situating relations between people. My use of wan also differs from the use of wan in other contexts such as that of Troolin's (2013) description of what it means to be wanbel. The wan as a prefix to lotu, strit and skul locates where relations are created, but I intend to show it is not place that evokes the sense of relatedness that people feel towards each other but rather mundane acts such as eating together, thinking about each other, as well as participation in exchange ceremonies of significance such as brideprice and mortuary feasts.

Adam Reed (2004: 123) writes that at Bomana jail a body of men is distinguished as being "one" (wan), of plural composition yet singular form. Male prisoners are sometimes brought together as wan banis (one fence). The distinction of being wan is what the prisoners share in common: being locked up and forced to abide by prison rules and also to justify mutual acts of assistance. At Bomana, the idiom wan can evoke any relation that encompasses other male prisoners. Interestingly, Reed's reference to this state of being wan is specific to bodies of men. Female prisoners at Bomana are said not to recognise unitary divisions but see themselves as "family". In Bomana, male prisoners transform themselves into bodies of men because of penal constraint and separation but this is not the case for female prisoners who identify separation as a moment of substitution, from one particular state to another. They replace kin ties with other kin ties.

My elicitation of wan differs from that of Adam Reed's portrayal of wan where "being one" is what men at Bomana aspire to, a state that is elicited as having kin taken away. On the contrary, wan 


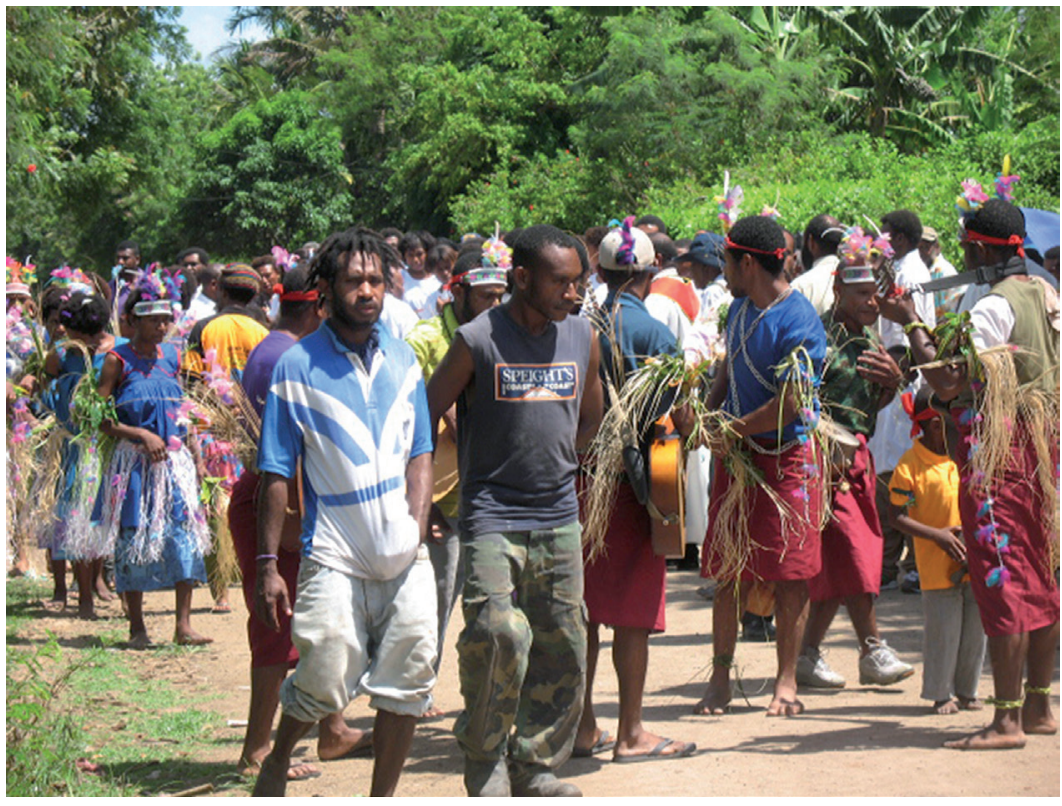

Picture 1. - Procession leading to the confirmation mass at Mr Zion Lutheran church, Morobe Blok, 2010 (C) Fiona Hukula)

in the Blok is not elicited as a consequence of an absence of kin, but as a display of relatedness in which wanstrit, wanskul, or wanlotu are used to locate the relationship. In establishing these social markers, the possibility of who might be called or treated as kin is widened. As in Bomana, the distinction is seen to characterise what people share in common: church, neighbourhood, educational background. However unlike Bomana, where the

"recognition of oneness is always a demand for support and expectation of obligation" (2003: 123),

in the Blok the recognition of oneness does not necessarily motivate a demand for support or an expectation of obligation because people who are "one" share other things which illuminate oneness. "Making one" in the Blok is possible through investment of time, money, food, warmth, and caring. It is this kind of action that transforms a wan into something that is like kin. Depending on the situation at hand, people present themselves in a plural form as wanlotu or wanstrit.

In thinking about relatedness in the Blok and urban Papua New Guinea in general, I look to the seminal work of Sandra Bamford who uses her ethnography of the Kamea to critique Euro-American assumptions that regard kinship as being rooted in biology, reproduced by individuals with a fixation on the parent-child tie as the connection that carries sociality forward (2007: 55). Bamford argues that the Kamea, unlike Euro-Americans, draw a sharp distinction between what goes into making a person - the substance that contributes to creation - and what connects them through time as social beings.
The Kamea expression of "one blood" differentiates persons in their social universe and is not an expression of genealogical connections as in the western world. For the Kamea, social relations are traced through time but are not based on physiological connections. It is the ties that people form with the land and the importance of tumbuna (ancestral stories) that enhance social relations. However, knowledge of stories is not enough to establish claims to land. For an individual to activate claims there must be investment of self to place (Bamford, 2009).

Taking Bamford as a point of reference, I want to show that communities that comprise what may be considered as a homogeneous group, such as Morobe Blok, form kin-like relations that are not solely based on provincial or clan allegiance but rather locate relatedness through continuous routine activities such as eating together, child rearing, sharing food, and praying together. These aspects of daily life, when carried out continuously over a long period of time, produce relatedness between people that at certain points in time can overshadow allegiances to clan and regional connections and form the basis of claims to people and places. I consider this form of urban relatedness to be an important facet of Melanesian urban sociality and will emphasise this aspect of urban life by first sharing my own experiences of negotiating this and then considering relationships within the Blok as examples of urban kin relations at work.

I want to capture the importance Blok imaginations of relatedness as a significant aspect of the everyday social lives of Blok people because it provides an insight into why certain people react to certain situations in certain ways. I use an ethnographic meta-narrative of a brideprice ceremony that I witnessed in the Blok. This brideprice event motivated me to think about ideas of relatedness in the Blok and the importance of the everyday interaction of Blok dwellers. Blok dwellers make claims to each other every day. However, relatedness is most prominent during events such as deaths and/or where a brideprice is exchanged. Given the importance that Melanesians place on these two events in the life cycle of a person, the urban haus krai 


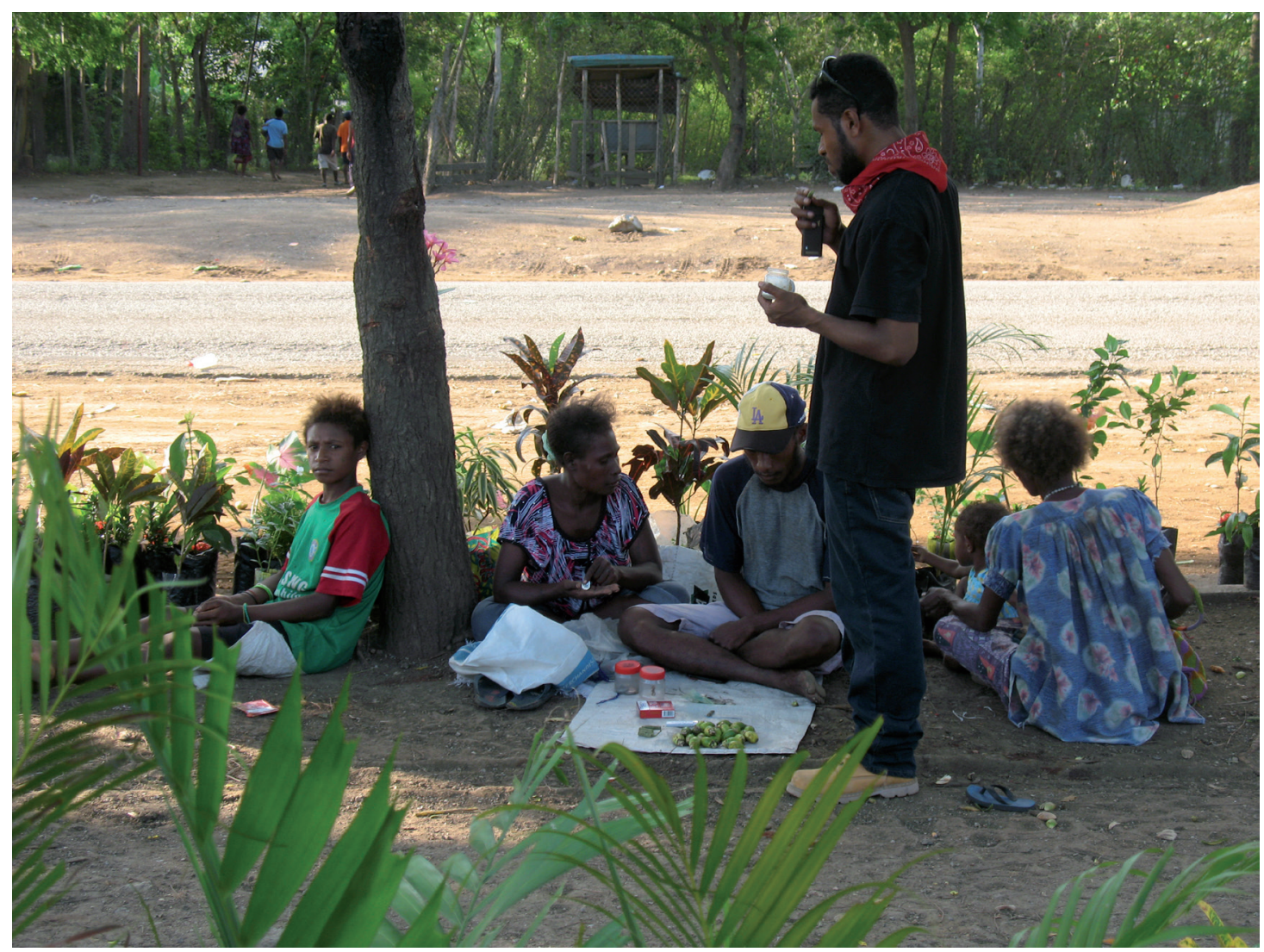

Picture 2. - Family sitting at the roadside market flower market, Port Moresby, 2010 (@ Fiona Hukula)

and brideprice ceremonies provide an opportune setting to observe how, what, and why relations appear at those precise moments.

In my observations as a Papua New Guinean attending such events in Port Moresby during my fieldwork time in the Blok, these particular public events made prominent a person's ordinary experiences of relatedness. It is at public events such as deaths and marriages that relations are articulated clearly and knowledge of why certain persons assume responsibilities in their capacity as a relation of blut or otherwise. It is a time when private relations are revealed. Private relations are the acts of relatedness that occur at a personal level between persons. At urban haus krais, wanskul, wanlotu, and wanstrit may sometimes claim relatedness in the same way as clansmen and blut relatives. It is with this in mind that I focus on Blok experiences of relatedness and relations through stories of routine everyday life, for it is these daily experiences that shape responses to public events such as deaths and marriages.

What follows from the brideprice story is a recollection of my own experiences of finding my way around the Blok. It is also a recollection of the process of locating myself that reflects multiple claims to my belonging. I focus on my own experience of introducing and explaining myself to people in the Blok as a consideration of how
Blok people interacted with me during the early days of my fieldwork. As a Papua New Guinean researcher, I was never just a sumatin (student) or wok meri blo gavman (woman who works for the government). Those who I met in the Blok were always interested in where I came from, and the initial discussions that I had with people were nearly always about place and belonging, which for me as a Papua New Guinean researcher was very helpful in placing myself in relation to the Blok. I use giving and not giving as the starting point to introduce Cynthia's story, which is intended to show how kin-like relations are formed through daily interaction and living and how this form of relatedness presents itself in the claims in which people make upon each other.

\section{Papua New Guinea lives here}

"Papua Niu Guinea yumi mas kamap wan nation, wan kantri, wan femli. Papua Niugini yumi mas kamap wan nation, wan solwara, wan pipol' [Papua New Guinea we must become one nation, one country, one family. Papua New Guinea we must become one nation, one sea, one people] (Barike Band of Rabaul, 1991) 
This song came to mind as I thought about a brideprice ceremony that I witnessed at Morobe Blok in January of 2010. Morobe Blok is predominately made up of Morobeans. The reality is, however, that there are also people from other parts of Papua New Guinea who reside at Morobe $B l o k$, and though small in number their presence does not go unnoticed and is certainly not ignored. Those who come from other parts of Papua New Guinea have their own connections to Morobeans, either through Blok friendships, church affiliation, or other relations such as marriage.

On occasions where there is confrontation, violence, or events such as deaths and marriages it was not uncommon to see people from different provinces participate as observers, mediators, and/or supporters. An example worth mentioning is a brideprice exchange I attended in the $B l o k$. I happened to be hanging around the buai (betelnut) market when I saw a large group of people singing and chanting as they entered the residence of a Blok resident who hails from the Simbu Province. I stood at a distance with other members of the people and watched members of the groom's family enter the yard of the relative of the bride's family.

After the groom's family entered the premises, the gate remained open and about five minutes after the singing had ended someone from inside the yard came out and invited us to witness the brideprice. Upon hearing the invitation, I went along with some of the buai and kumu (green leafy vegetables) sellers to watch the event. As the designated master of ceremony began talking he acknowledged that they were from Simbu and lived in Morobe Blok. He then went on to say that in reality there were people from all over PNG who live in the Blok and therefore he took the opportunity to welcome the Simbus, the Morobeans and, in his words, "the rest of Papua New Guinea" who had joined them to witness the occasion. What I find telling in the few words "the rest of Papua New Guinea" is the recognition of difference in that we were all from different parts of Papua New Guinea as well as the importance of similarity. We all were part of this place called Morobe Blok and our connection to this place was what seemed important at this particular occasion. It is recognition of a multiple sense of place in which urban dwellers identify with and claim to belong to that is foregrounded because apart from the Motuan people, no one can really ever be referred to as being solely from Port Moresby for everyone is believed to have come from elsewhere.

To make this more explicit I share my own experience of meeting people and trying to find my way around the Blok. My first encounter with Blok residents would usually result in the person I was speaking with asking me

\section{"Where are you from?"}

with me automatically replying "Sepik". I would maybe get a reply that went something like

\footnotetext{
"ah sepik dirty wara, ol lain blo kaikai saksak." [Sepik dirty river, people who like to eat sago. $]^{4}$
}

Then when I further added that I was actually born and raised in Port Moresby, I would know the comments of

$$
\begin{aligned}
& \text { "o yu Sepik blo Moresby" would follow [Oh, so you } \\
& \text { are a Sepik from Moresby.] }
\end{aligned}
$$

For those who are long-time Moresby residents like myself the conversation would proceed on to where in Port Moresby I grew up, which often resulted in me being further defined as a "meri Toks" [Toks lady]. These references to place and space not only defined me as a Port Moresby resident, but also served as an example of how people locate relatedness through time in the urban context.

\section{Making kin}

People in urban spaces like Port Moresby find themselves in situations where relatedness can be objectified through wan wok, wanstrit, and wanlotu. These particular relations become a part of urban life and influence actions in numerous ways, one of which is how one chooses to give or not give. For example, tensions of not having money are not always resolved through having money. Having money brings its own tensions of how and who to spend this on because giving and sharing is one way that Blok residents cultivate relations with each other. Worries about how to spend money coupled with ideals of giving and the importance of certain relations, inform the ways in which one chooses to give.

Giving to one who is not considered a blut relative opens the possibility for reciprocity and the building of relations between people that may result in the formation of lifelong associations. Giving and sharing are not only limited to money and material goods. Giving in the form of time, help, and thinking about others is also a significant aspect of urban sociality. The continuous investment in relationships through

3. Meaning to come from the East Sepik.

4. This reaction is based on a common assumption that identifies all Sepiks with the Sepik River, crocodiles and sago.

5. Moresby residents often refer to themselves as being from the suburbs that they grew up in. 
time, sharing, and giving creates relatedness between urban dwellers, which in my observation, expands one's kinship options and informs thinking about relatedness. On the other hand, sharing of food, time, and money with those who are not blood or clan related can lead to animosity among families if the claims of "blood" relatives to people and things are overlooked by relations with people who would normally be seen as narapela lain (outsiders).

As much as lack of money causes tension in one's life, having money also has the ability to cause tension. When people have money, they have to think about how to share the often little or sometimes not so little amount that they have. My friend John said to me,

"My $a m b o^{6}$ it's tough-I occasionally get an allowance as a volunteer and that is next to nothing. Sometimes I want to buy my kids something extra but their cousins are around and I can't just buy stuff for my kids and not for their cousins. So it's hard to have money because it's not good not to share. If you share then you will be blessed."

Although people consistently talk about the need for money, it is not money itself that drives these tensions. Rather it is the recognition of social relational duties that motivates these anxieties.

Thoughts about giving do not only affect daily life but also affect the way in which people are represented or how they present themselves at occasions of social importance such as haus krai (mourning houses) or brideprice ceremonies. For urban dwellers, this can be an extremely expensive exercise as haus krai require food and even more expenses if the deceased person is to be repatriated to a home province. Expectations of rural kin coupled with the knowledge that one's contribution to clan and village activities will keep relations between an urban dweller and his or her ples in view is an important consideration for Blok dwellers. The majority of households that participated in a household survey that I conducted stated that they remitted money to their relatives in various parts of the country as well contributed to haus krai in Port Moresby. In this regard, money problems are not only limited to daily physical survival but also affect one's ability or inability to represent oneself at occasions of importance where people's status as members of their group is measured. Such expectations of giving directly influence Blok people's views and understanding of kinship and personhood.

Urban living has added another dimension to the strong clan and tribal affiliations that Papua New Guineans know, which enables urban residents to form lasting kin-like relations with those who are not from the same clan, tribe, or province. In a settlement community such as Morobe Blok, it may be expected that shared province (wantok) origins are enough to define kin-like relations. My fieldwork experience showed me that even though I lived in a community that is seen as wan because residents are mostly from the same province, I still found that within the Blok differences between Morobeans were highlighted and sometimes it was affiliations to lotu or strit that were more significant than being from the same province.

\section{Everyday relatedness}

Blok people often talked about sharing food and eating together. On many occasions, I saw groups of people or individuals openly sharing food. For example, there was a group of young boys who had a maket table set up from which they sold buai, cigarettes, and lollies. At any one time, there would be two or three boys sitting around the maket table. If one boy went and bought a scone most times he would share with the others regardless of how hungry he was. These relations are often described through wanstrit, wanlotu, or wanskul.

I learned to recognise relationship patterns based on how people approached, greeted, and made demands upon each other when food was present. Those who had a kin-like relationship openly made demands to share food. It was not uncommon to hear one person say to another "hap kam" (half come). To say "hap kam" indicates a certain historical familiarity of sharing. One would not ask someone with whom they did not have a relationship of familiarity to give food as this would be considered shameful. It was also not unusual for persons who have that sort of familiar relationship to ask another to buy food such as scones or biscuits. My observations reinforce the importance of food and eating together as observed by early ethnographers of the Highlands such as Strathern (1973).

Wanlotu frequently gather for prayer meetings and worship. For example, members of the Revival church gathered on Tuesday and Thursday afternoons to have fellowship together. In some instances, preference was given to wanlotu in situations such as bisnis transactions. Those who were wanstrit also helped each other practically with food or childcare. Men and women who grew up together often referred to the husbands or wives of their wanstrit as tambu (in-laws). But could this be seen as friendship? I argue that the line between friendship and kinship is quite blurred. I do not recall anyone using the word friend to describe a relationship between 
two unrelated persons. The word "squad" is the closest description to friend that I noted (Kraemer, this issue, pp. 105-116). Most people used kinship terms locating the relationship in a place (school, street, or church).

Everyday relatedness is made through exchange. Caring for another, whether it be an old or young person, creates relatedness between people rooted in a wan relation such as wanstrit. I elaborate on this point through an account of Sarah, Cynthia, and Toby. This provides a Blok example of one way in which kinship is made, and an example of how kin-like relations are created between children and adults who are not "blood" mothers or fathers. The story has two parts. It is about relations between a little boy and his babysitter (child minder) and it is also about the relationship between two women who are friends and also employer and employee.

\section{He's my son: Toby and his Mama Cynthia}

Sarah is a dynamic health worker and liklik bisnis meri (small businesswoman). She lives in the Blok with her husband and three children and commutes to town to work at the Port Moresby General Hospital. I met Cynthia through Sarah. Cynthia worked for Sarah as a babysitter caring for Sarah's five-year-old son. Cynthia who is now married with her own children began caring for Toby when she was a teenager. When Toby was a baby he often slept at Cynthia's house when his mother was rostered to work a night or evening at the hospital.

For Cynthia, her job as a child minder merged with the rest of her life outside of her work. The fact that she was paid to care for Toby was eclipsed by how she thought of Toby as her son and not as a little boy who she cared for as a means to earn cash. Toby spent time with Cynthia on weekends and on days when she was not meant to be caring for him. A keen soccer player, Cynthia played for a team in the Blok competition. She described how she played soccer on Sunday afternoons and Toby would come to the field with his mother Sarah and start crying and screaming for Cynthia to carry him. Cynthia told me that Toby was like a son to her.

"I'm his mother. I have been taking care of him since he was a little baby and even slept in the hospital and took care of him when he was really sick and admitted to the children's ward at Port Moresby General Hospital. Now he is a bit older he has stopped crying for me. I began looking after Toby when I was young and now that I am married he calls my husband daddy. My husband knows that Toby is like my very own because he would see me carrying Toby around the Blok when I was single."
Although Cynthia is not Toby's biological mother she is an acknowledged mother because she cares for him as if he were her own child. Toby himself claims Cynthia as his mother by referring to her as "mama Cynthia". Even though Cynthia was a teenager when she started caring for Toby and had never been married or had a child of her own, she was already a mother through her relationship with Toby.

I use kinship terms such as "mother", "brother", or "sister" to describe relatedness in the Blok or Port Moresby also because it is common for a stranger to refer to another stranger as "brother" or "sister", "mother", or "father". For example, children begging in the streets of Port Moresby usually address those who they ask for food or money as "mams" or "paps" (mother or father). The use of these terms in conversations emanates from both a Christian mode of thought, in the use of kinship terms such as "brother" or "sister, and also from a cultural practice in some parts of Papua New Guinea where people do not call others by name but instead use kinship terms as substitutes.

In the case of Cynthia and Toby, it is the care and love that Cynthia showed Toby through time and the affection that he returned to her and her family members that shaped their relatedness claims to each other. Susan Viegas' (2003) ethnographic account of time and sociality in a Caboclo-Indian community of south Bahia, Brazil similarly explores time as a factor in how kinship between a mother and child is formed through the long-term repetition of small acts such as feeding, dressing, or bathing.

Viegas, following Toren (1996, 1999), analysed the process whereby children become aware of themselves through acts of feeding and nurturing by adults. She demonstrated that Caboclo Indians are deeply aware that if they stop performing these small acts then the link between parents and children will be weakened or severed; hence, her article "Eating with Your Favourite Mother" not only discusses the temporal aspects of sociality and kinship making, but the possibility of unmaking kin through the cessation of feeding and nurturing. Viegas showed how children identify with women in their compound, such as their grandmothers or "focal mothers" (Viegas' term), as mother-like because they feed, clothe, and take care of them on occasions when their mothers go to work for the day, or if they are in the postpartum period of childbirth.

These 'substitutions' of mother-like activities happen on a regular basis and are repeated throughout a child's life; therefore, children form strong bonds with their focal mothers which may lead to the child choosing to eat at its focal mother's house rather than the house of the birth mother. This is an important feature 
of mother-child relations because the house in which the child chooses to eat is the house where the child chooses its mother. What is of interest to me is Viega's assertion that choosing one's mother is a way of emphasizing the possibility of unmaking parent-child links (Viegas, 2003: 32) and how the intersubjective relationship between the adult and the child based on pleasing and attraction, which is expressed in the local notion "agradar" (to please, in Portuguese), feeds and motivates acts between adults and children.

Coming back to my own ethnographic example, Toby chooses Cynthia as his mother but he also recognises and acknowledges his own mother Sarah. He is fed and nurtured by both women and addresses them both as "mama". Sarah herself refers to Cynthia as "mama blo Toby" (Toby's mother). As I mentioned earlier, Cynthia was newly married when I met her. She had just married Rusty, a young man from the Gulf Province, and together they had adopted a little girl from Cynthia's side of the family. Cynthia was also pregnant with their second child. Cynthia continued to mind Toby until she gave birth to her daughter after which her younger sister Rita helped to take care of Toby. Toby continued to visit Cynthia's house regularly even though she was officially not his babysitter anymore. The notion of "feeding and nurturing" as a constitution of kinship or one's knowledge of what constitutes relatedness and kinship (Toren, 1999; Carsten, 1995; Gow, 1991) is evident in Toby's continued association with Cynthia after she effectively ceased being paid to care for him. In this instance, one could also infer that the proximity of Cynthia living in the same area as Toby allowed this relationship to flourish.

However, I think that it is more than this given the relationship between Cynthia and Toby's siblings, Rena and Seth. Toby's claim to Cynthia as "mama" emanates from their relationship. Sarah told me that Cynthia was Toby's mother and not Rena's because Rena was already a big girl (toddler) when they moved to the Blok from Sabama (Port Moresby suburb) and as she was cared for by Sarah's relatives at Sabama she had more of an affiliation to family at Sabama and often went to visit and stay with them when she was on school holidays.

For this reason I suggest that for Cynthia and Toby it is not really about choosing one mother over another. It is not mutual attraction in the sense that a child will unmake parent-child links by choosing to eat in his favourite mother's house, but more about the multiple claims that one can have on another based on caring and feeding. Toby knows that his mother is Sarah and his relationship with Cynthia could change now that she has her 'own' family and is no longer Toby's caregiver leading to the unmaking of their mother-child relationship.
However, I think Cynthia and Toby's motherchild relationship will be sustained through their memories of feeding and caring. The mutual story of relatedness will sustain the relationship between Cynthia and Toby. I draw again on Sandra Bamford who argued that the Kamea draw a sharp distinction between what goes into making a person in a physical sense and what connects them through time as social beings (Bamford, 2009: 162). Kamea trace social relations through time not through physiological connections but through ties with the land. In the urban setting, Blok people also recognise the contribution of substance through maternal and paternal actions but equally, as I have shown through Cynthia and Toby's story, social relations can emerge through time based on everyday activities. Where the Kamea make claims to relations based on shared land, Blok people also trace relations through time based in the particular landscape known as the Blok and specifically by continuous everyday actions and exchanges that serve to constitute kinship.

\section{They're my family: Sarah and Cynthia's story}

The relationship between Sarah and Cynthia extended beyond the employer/employee relationship in that both Sarah and Cynthia associated regularly when Cynthia was not working. Cynthia's family also spent time at Sarah's place and vice versa. Their relationship took on a form of relatedness that transcended that of employer/ employee to that of kinship. Sarah not only opened her home to Cynthia as the carer of her child, but she also welcomed Cynthia's parents and siblings. Hence, Cynthia's parents often visited Sarah's place chopping fire wood or helping Sarah take care of her poultry.

Some may see this as a power dynamic between Sarah and Cynthia because the money that Sarah paid Cynthia effectively provided for her family, and therefore it was important that the relationship continued. Research with $\mathrm{Ni}$ Vanuatu haosgels showed that paying a family member to become a house girl is common in Vanuatu with family relationships being commoditised (see Jourdan, this issue, pp. 131-146). This may transform relations between the families involved (Rodman et al., 2007: 9). Such is also the case in Moresby where village relatives come to town to care for children where they are in some instances mistreated. It could be argued that money created a power imbalance between Sarah and Cynthia's family. However, in this case I argue that for Sarah, Cynthia and her family not only provided domestic help, but importantly also the family support that she needed. In return for their help, Sarah assisted Cynthia's 
parents when they were ill by giving them money to pay for medication at the local clinic or by cooking food for them. Sarah also visited Cynthia's family regularly to chew buai, sometimes cooked corn or kaukau (sweet potato) over the fire, and shared stories. Sarah's husband sometimes parked his car at Cynthia's family home when the road was too muddy to drive to their own house.

While the two families interacted regularly on a daily basis, there was some tension especially when Sarah's mother-in law-visited Sarah and her family. At these times Cynthia and her family were noticeably absent from Sarah's place. When I asked Sarah why Cynthia stopped coming around, Sarah replied that her mother-inlaw who was staying with them did not approve of Cynthia and her family being around all the time. Sarah said to me,

"I don't care what they [affines] think, I want Cynthia and her family to come to my house, they are my family, I'm not from Morobe, I don't have any family here and my tambus are not good to me. They won't help me; they expect that I must give them money before they help to look after the kids. But Cynthia, she is like Toby's mother, he cries for her and gets sick if his grandmother [paternal] doesn't allow him to go to Cynthia’s house."

When Toby was sick for days Sarah took him to Cynthia's house before she went to work in the morning. When she returned from work in the afternoon, Toby was running around Cynthia's yard and Sarah concluded that Toby only felt sick because his grandmother did not allow him to go to Cynthia's house and because Cynthia stopped coming to Sarah's house.

Sarah has created her own family in a place where she lives among her affines. Though she does have close family members living in Moresby, she has chosen to create her own family in the Blok by converting an employer/employee relationship into a familial one. Relationships like that of Cynthia and Sarah sustain many lives within the settlement, not only in material terms but also in the context of hevi (problems).

Blok people acknowledge kin relations through substance, clan, and tribal affiliations, but they also establish relatedness through sharing, feeding, and thinking about one another. Non-genealogical aspects of kinship in the Blok are important elements of urban experience. People in town build kin-like relations using the concept of wan, particularly wantok, wanstrit, and wanlotu.

\section{REFERENCES}

BAmford Sandra, 2007. Biology Unmoored. Melanesian Reflections on Life and Biotechnology, Berkeley, University of California Press.

—, 2009. "Family Tree" among the Kamea of Papua New Guinea. A non genealogical approach to imagining relatedness, in S. Bamford and J. Leach (eds), Kinship and Beyond: The Genealogical Model Reconsidered, New York, Berghahn Books, pp. 159-174.

Carpenter Jessica and Jenny Munro, 2016. Women's Livelihoods in Honiara Settlements. State, Society and Governance in Melanesia, Canberra, ANU In Brief 2016/31.

Carsten Janet, 2000. Knowing where you've come from: Ruptures and Continuities of time and kinship. Narratives of Adoption Reunions, Journal of the Royal Anthropological Institute 6 (4), pp. 637-53.

—, 2004. After Kinship, Cambridge, Cambridge University Press.

Gow Peter, 1991. Of Mixed Blood, New York, Oxford University Press.

—, 1995. Land, People and Paper in Western Amazonia, in Eric Hirsch and O'Hanlon Michael (eds), The Anthropology of Landscape: Perspectives on Place and Space, Oxford, Clarendon Press, pp. 43-62.

Leach James, 2003. Creative Land. Place and Procreation on the Rai Coast of Papua New Guinea, Oxford, Berghahn Books.

Lindstrom Lamont, 2011. Urbane Tannese: Local Perspectives on Settlement Life in Port Vila, Journal de la Société des Océanistes 133, pp. 255-266 (https://jso.revues.org/6461).

Mannan Muhammad Abdul, 1978. Group Norm and Developmental Change in Papua New Guinea, in Mamak Alexander and Grant MCcall (eds), Paradise Postponed: essays on research and development in the south pacific, Sydney, Young Nations Conference, pp. 198-208.

Monsell-Davis Michael, 1993. Safety Net or Disincentive? Wantoks and Relatives in the Urban Pacific, Waigani, National Research Institute, Canberra Anthropology 16 (2), pp. 45 66.

Mohanty Manoranjan, 2011. Informal Social Protection and Social Development in Pacific Island Countries: Role of NGo's in Pacific Island Countries, Asia Pacific Development Journal 18 (2). 
NanaU Gordon, 2011. The Wantok System as a socio-economic and political network in Melanesia, The Journal of Multicultural Society 2 (1), pp. 31-55.

National Statistics Office, 2000. 2000 National Census: National Capital District Report, Port Moresby, Natoional Statistics Office.

Reed Adam. 2004. Papua New Guinea's Last Place. Experiences of Constraint in a Papua New Guinea Prison, Oxford, Berghahn.

Renzio Paolo (De), 2000. Big Men and Wantoks: Social Capital and Group Behaviour in Papua New Guinea, QEH Working Paper Series, Oxford, University of Oxford (https://ideas. repec.org/p/qeh/qehwps/qehwps27.html).

Rodman Margaret, Daniela Kraemer, Lissant Bolton and Jean TARISESEI (eds), 2007. House Girls Remember: Domestic Workers in Vanuatu, Honolulu, University of Hawai'i Press.

Rooney Michelle N., 2015. Money and values in urban settlement households in Port Moresby Part 1: Money is important, so are children, water and firewood, in State, Society and Governance in Melanesia, Canberra, ANU in Brief 2015/18.

Schram Ryan, 2015. Notes on the Sociology of Wantoks in Papua New Guinea, Anthropological Forum 25 (1), pp. 3-20.
Stafford Charles, 2000. Chinese Patriliny and the cycles of yang and laiwang, in J. Carsten (ed.), Cultures of Relatedness. New Approaches to the study of kinship, Cambridge, Cambridge University Press, pp. 37-54.

Strathern Andrew, 1973. Kinship, Descent, and Locality: Some New Guinea Examples, in J. Goody (ed.), The Character of Kinship, Cambridge, Cambridge University Press, pp. 21-33.

Strathern Marilyn, 1975. No Money on Our Skins. Hagen Migrants in Port Moresby, Port Moresby, New Guinea Research Unit.

Toren Christina, 1996. Debate: the concept of society is obsolete: for the motion (2), in T. Ingold (ed.), Key Debates in Anthropology, London, Routledge, pp. 72-74.

- 1999. Compassion for one another: constituting kinship as intentionality in Fiji, Journal of the Royal Anthropological Institute 5 (2), pp. 265-280.

Troolin David, 2013. Navigating contested terrain: vernacular education in a Papua New Guinean Village, Current Issues in Language Planning 14 (2), pp. 283-289.

VIEgas Suzanna D., 2003. Eating with your Favourite Mother: Time and Sociality in a Brazialian Community, Royal Anthropological Institute 9 (1), pp. 21-37. 